\title{
Elaboration of Blends of Pitaya Pulps With Acerola
}

\author{
Maria S. de Moraes ${ }^{1}$, Rossana Maria Feitosa de Figueirêdo ${ }^{1}$, Alexandre J. de M. Queiroz ${ }^{1}$, Luís P. F. R da Silva ${ }^{1}$, \\ Mailson G. Gonçalves ${ }^{1}$, Adolfo P. de Oliveira ${ }^{2}$, Janaina A. D. Esmero ${ }^{1}$, Nágela M. H. Mascarenhas ${ }^{1}$, \\ Joana D. P. de Matos ${ }^{3}$, Semirames do N. Silva ${ }^{1}$, Dannaya J. G. Quirino ${ }^{4}$, Airton Gonçalves de Oliveira ${ }^{1}$, \\ Agdylannah F. Vieira ${ }^{1}$, Morgana A. Araújo ${ }^{1}$, Moisés Sesion de M. Neto ${ }^{1}$, Francislaine S. dos Santos ${ }^{1}$,

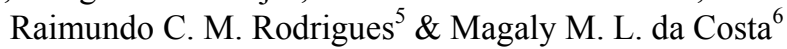 \\ ${ }^{1}$ Federal University of Campina Grande, Campina Grande, Brazil \\ ${ }^{2}$ Federal University of Santa Catarina, Florianópolis, Brazil Brazil \\ ${ }^{3}$ Federal University of Rio Grande of Norte, Macaíba, Brazil \\ ${ }^{4}$ University of São Paulo, Pirassununga, Brazil \\ ${ }^{5}$ Department of Agricultural Engineering, State University of Maranhão, São Luís, Brazil \\ ${ }^{6}$ Brazil Teacher of the Paraíba State Network, São Bento, Brazil \\ Correspondence: Mailson G. Gregório, Federal University of Campina Grande, Campina Grande, PB, Brazil. \\ E-mail: gregoriomailson@gmail.com
}

Received: December 5, 2020

Accepted: January 4, 2021

Online Published: February 15, 2021

doi:10.5539/jas.v13n3p53

URL: https://doi.org/10.5539/jas.v13n3p53

\begin{abstract}
Pitaya and acerola are fruits rich in nutrients and can be used in blends formulation in order to improve the sensory characteristics of both pulps in isolation and complement each other in terms of nutritional aspects. Thus, the aim of this research was to develop different blends of pitaya pulp with acerola and choose the best formulation based on physical-chemical and colorimetric characteristics. Three blends formulations were prepared: F1-90\% pitaya and 10\% acerola; F2-70\% pitaya and 30\% acerola; and F3-50\% pitaya and 50\% acerola The formulations were evaluated for physical-chemical parameters of water activity, water content, ash, total soluble solids (SST), pH, total titratable acidity (ATT), SST/ATT ratio, ascorbic acid, proteins, lipids, sugars totals, reducers and non-reducers and colorimetric analysis. The obtained data were subjected to variance analysis (ANOVA) and to comparison between means by the Tukey test at 5\% probability. The formulation F1 stood out when compared to the others. The parameters $\mathrm{pH}$, soluble solids, ratio SS/ATT, ash, water content, water activity, proteins, sugars, luminosity and hue angle were the ones that gave the formulation F1 the best results. However, it is noteworthy that the formulation F3 presented a greater amount of ascorbic acid and higher values of $\mathrm{a}, \mathrm{b}$ and chroma in the colorimetric analysis. The use of these fruits allows to obtain an innovative product with excellent nutritional and functional characteristics. The blend is a viable alternative for the use of perishable and seasonal fruits, adding greater economic value to the very promising product to the market.
\end{abstract}

Keywords: fruits, Hylocereus undatus, Malpighia emarginata, new products, processing

\section{Introduction}

Brazil has a great diversity of fruits produced and sold nationwide, however, in parallel there is a great waste due to perishability and/or inadequate storage. It is estimated that around $50 \%$ of the volume produced is lost in the post-harvest stages, thus limiting commercialization in other markets more distant from the place of production (Silva et al., 2016; Lima et al., 2018).

Pitaya is a tropical fruit belonging to the Cactaceae family. In Brazil, its production is concentrated in the Southeast region, in the state of São Paulo, however, the interest in the fruit is growing, due to being exotic and its peculiar nutritional and sensory properties (Molina et al., 2014; Ortiz \& Takahashi, 2015). The species Hylocereus undatus has white colored pulp and red skin, and Hylocereus polyrhizus has intense red colored skin and pulp (Wong \& Siow, 2015).

The red white pulpy pitaya (Hylocereus undatus) is one of the most cultivated species in Brazil, and has been arousing great interest on the part of the producers for its high productive capacity and the great acceptance in 
the export market, providing highly compensatory economic gains, in addition to constitute an excellent source of nutrients (Fernandes, 2011).

As for the nutritional composition, pitaya stands out for its high content of fibers, minerals (iron and zinc), vitamin $\mathrm{C}$ and $\mathrm{A}$ and also the content of bioactive compounds (pigments and phenolic compounds). The presence of these antioxidant substances has aroused interest in this fruit due to the potential beneficial effect of these substances on human health (Nunes et al., 2014).

Acerola (Malpighia emarginata), a member of the Malpighiaceae family, originated in Central America, is a fruit of high acidity, low $\mathrm{pH}$ and sugars, a very expressive content (1000 to $4500 \mathrm{mg} \cdot 100 \mathrm{~g}^{-1}$ ) and contains a multitude other phytonutrients, such as phenolic compounds, flavonoids, anthocyanins and carotenoids (Almeida et al., 2014; Delva \& Schneider, 2013; Prakash \& Baskaran, 2018).

The processing of these fruits in the form of blends is an alternative to minimize surpluses during the harvest season and add value to the fruits, offering the competitive market new products, with better properties of the fresh fruit and greater use of its functional properties. Blends are mixtures of juices or pulps, elaborated with the purpose of improving the sensory characteristics, enhancing the nutritional part of the product, either by its high content in vitamins or by its functional characteristics, such as antioxidants (Silva et al., 2014).

The elaboration of fruit blends allows the creation of innumerable new products with characteristics that can be chosen according to the profile of the consumer to be reached. Depending on the chosen combination, you can have products with higher levels of certain nutrients, with specific colors, as well as varied flavors and aromas (Lemos et al., 2013).

Blends of pytaia and acerola pulps make up a new product, with nutritional characteristics of the two pulps, with different flavors and aromas. The chemical composition of each fruit used adds up and affects the final characteristics of the products obtained, so the objective of this work was to carry out the physical-chemical characterization and colorimetry of different formulations of pitaya and acerola pulp blends elaborated with different proportions of pulps.

\section{Method}

\subsection{Acquisition of Raw Material and Research Location}

The fruits of acerola (M. emarginata) and pitaya (H. undatus) were acquired in the commerce of the city of Campina Grande-Paraíba, Brazil. A research carried out at the Agricultural Products Storage and Processing Laboratory (LAPPA) at the Federal University of Campina Grande, Campina Grande Campus.

\subsection{Processing of Fruits and Blends Elaboration}

The fruits were initially selected for their maturation stage, washed in running water to remove dirt and sanitized in chlorinated solution (100 ppm of active chlorine) for $15 \mathrm{~min}$ and rinsed in running water, crushed in a multiprocessor to produce the pulps, which they were then homogenized in a domestic blender (Walita ${ }^{\circledR} 1500$ W). The whole process was carried out separately for each type of fruit. After obtaining the pulps, three blending formulations were prepared: $\mathrm{F} 1-90 \%$ pitaya and $10 \%$ acerola, $\mathrm{F} 2-70 \%$ pitaya and $30 \%$ acerola, $\mathrm{F} 3-50 \%$ pitaya and $50 \%$ acerola.

\subsection{Colorimetry Analysis}

The pulp blends were evaluated, in triplicate, for the color determined by direct reading using the MiniScan HunterLab XE Plus spectrophotometer, model $4500 \mathrm{~L}$, with a Cielab color system. The parameters determined were: $L^{*}$, which represents the luminosity, that is, the transition from black (0) to white (100); $\mathrm{a}^{*}$ which represents the transition from green $\left(-\mathrm{a}^{*}\right)$ to red $\left(+\mathrm{a}^{*}\right) ; \mathrm{b}^{*}$ the transition from the intensity of the blue color $\left(-\mathrm{b}^{*}\right)$ to the yellow color $\left(+b^{*}\right)$. From these parameters, the values of chroma $\left(c^{*}\right)$ and tint angle $\left(\right.$ angle $\left.h^{\circ}\right)$ were calculated. The water activity at $25^{\circ} \mathrm{C}$ was performed by direct reading of the sample on the Aqualab model $3 \mathrm{TE}$ equipment (Decagon Devices, Inc.).

\subsection{Physicochemical Characterization}

The following physical-chemical parameters were also analyzed, according to the analytical procedures of the Adolfo Lutz Institute (Brasil, 2008): $\mathrm{pH}$ in a digital pot; water content through direct drying in a vacuum oven $\left(70{ }^{\circ} \mathrm{C}\right)$; ash by muffle incineration at $550{ }^{\circ} \mathrm{C}$; titratable total acidity by titration with $0.1 \mathrm{M} \mathrm{NaOH}$; total soluble solids ( ${ }^{\circ}$ Brix) by direct reading on a digital refractometer; protein content quantified according to the Kjeldahl method; lipids determined by the methodology of Bligh and Dyer (1959) with chloroform, methanol and water; total and reducing sugars were determined by the Fehling method by hot titration, and non-reducing sugars 
obtained by the difference between total and reducing sugars. The SST/ATT ratio was obtained by the ratio between total soluble solids (SST) and total titratable acidity (ATT).

The ascorbic acid content was determined by titration with 2.6 dichlorophenolindophenol sodium (DCFI) until the light pink, persistent color was obtained, using oxalic acid (Benassi \& Antunes, 1988) as an extracting solution following the AOAC (2009) procedure.

\subsection{Statistic Analyzes}

The experiment was installed in a completely randomized design, with three replications. The data were subjected to analysis of variance (ANOVA) and according to the significance of the F test, Tukey's test was applied at 5\% probability, using the computer program ASSISTAT, version 7.7 Beta (Silva \& Azevedo, 2016).

\section{Results and Discussion}

Table 1 shows the average values of the analyzed parameters of blends of pitaya pulp with acerola. The mean $\mathrm{pH}$ values showed statistical difference between the formulations. It is observed that according to the increase in the concentration of the acerola pulp, there was a decrease in $\mathrm{pH}$ and an increase in the total acidity content. Low $\mathrm{pH}$ values are a preferable condition by the industry, since during processing this condition promotes a decrease in enzymatic activity and microbial growth.

Brazilian legislation portrays minimum $\mathrm{pH}$ levels (2.8) and total titratable acidity $\left(0.8 \mathrm{~g} \cdot 100 \mathrm{~g}^{-1}\right)$ for acerola pulp, however, for pitaya pulp it is not defined (Brasil, 2018). Thus, considering only the requirements for acerola pulp, it is observed that the formulations showed $\mathrm{pH}$ and total titratable acidity above the minimum required by it.

Bezerra et al. (2013) when evaluating the mixed juice of tropical fruits (5\% acerola pulp, $10 \%$ passion fruit pulp and $20 \%$ taperebá pulp) obtained a $\mathrm{pH}$ equal to 3.3 , lower than that obtained in the three formulations of this research. Reis et al. (2017) reported total titratable acidity of 1.12\% and Souza et al. (2015) of $1.33 \%$ citric acid for the acerola pulp. In the study by Braga et al. (2020) with mixed nectar of pitaya and passion fruit, detected $\mathrm{pH}$ values ranging from 4.30 to 4.40 , above that found in the present study. Total titratable acidity ranged from 0.38 to $0.62 \mathrm{~mL} \cdot 100 \mathrm{~mL}^{-1}$ close to that reported in the present study.

Table 1. Average values and standard deviations of the physical-chemical parameters evaluated in pitaya blends with acerola.

\begin{tabular}{llll}
\hline \multirow{2}{*}{ Parameters } & \multicolumn{3}{c}{ Formulations } \\
\cline { 2 - 4 } & F1 & F2 & F3 \\
\hline pH & $4.13 \pm 0.01 \mathrm{a}$ & $3.77 \pm 0.01 \mathrm{~b}$ & $3.56 \pm 0.01 \mathrm{c}$ \\
Total titratable acidity (\% citric acid) & $0.46 \pm 0.01 \mathrm{c}$ & $0.68 \pm 0.01 \mathrm{~b}$ & $0.91 \pm 0.02 \mathrm{a}$ \\
Total soluble solids $\left({ }^{\circ}\right.$ Brix) & $11.87 \pm 0.12 \mathrm{a}$ & $10.30 \pm 0.10 \mathrm{~b}$ & $9.46 \pm 0.12 \mathrm{c}$ \\
Ratio SST/ATT & $25.43 \pm 0.57 \mathrm{a}$ & $15.07 \pm 0.26 \mathrm{~b}$ & $10.41 \pm 0.26 \mathrm{c}$ \\
Ashes (\%) & $0.57 \pm 0.01 \mathrm{a}$ & $0.54 \pm 0.01 \mathrm{~b}$ & $0.44 \pm 0.01 \mathrm{c}$ \\
Water content $(\%)$ & $87.96 \pm 0.16 \mathrm{c}$ & $88.95 \pm 0.24 \mathrm{~b}$ & $89.86 \pm 0.13 \mathrm{a}$ \\
Water activity at $25^{\circ} \mathrm{C}$ & $0.989 \pm 0.001 \mathrm{a}$ & $0.992 \pm 0.002 \mathrm{a}$ & $0.991 \pm 0.001 \mathrm{a}$ \\
Ascorbic acid (mg.100 g) & $162.16 \pm 2.85 \mathrm{~b}$ & $167.34 \pm 3.79 \mathrm{~b}$ & $194.35 \pm 3.51 \mathrm{a}$ \\
Lipids $(\%)$ & $0.13 \pm 0.03 \mathrm{a}$ & $0.13 \pm 0.03 \mathrm{a}$ & $0.14 \pm 0.05 \mathrm{a}$ \\
Proteins $(\%)$ & $0.71 \pm 0.05 \mathrm{a}$ & $0.66 \pm 0.05 \mathrm{a}$ & $0.63 \pm 0.09 \mathrm{a}$ \\
Total sugars $(\%$ glucose) & $13.87 \pm 0.33 \mathrm{a}$ & $11.70 \pm 0.47 \mathrm{~b}$ & $10.50 \pm 0.09 \mathrm{c}$ \\
Reducing sugars $(\%$ glucose) & $9.18 \pm 0.21 \mathrm{a}$ & $7.66 \pm 0.26 \mathrm{~b}$ & $8.87 \pm 0.20 \mathrm{a}$ \\
Non-reducing sugars $(\%$ sucrose) & $4.45 \pm 0.28 \mathrm{a}$ & $3.84 \pm 0.68 \mathrm{a}$ & $1.55 \pm 0.28 \mathrm{~b}$ \\
\hline
\end{tabular}

Note. Means followed by the same letter on the line, do not differ statistically from each other by the Tukey test at the level of $5 \%$ probability.

The total soluble solids (SST) content of the blends ranged from 9.46 to $11.87^{\circ}$ Brix. Note that $\mathrm{F} 1$ had a higher content. In the current legislation the minimum required content of total soluble solids (TSS) for acerola pulp is $5.5^{\circ}$ Brix, so the formulations studied are within the minimum required values. The main sugars in fruits are: glucose, fructose and sucrose in varying proportions, according to the species. Considering the low acidity and the high SST content, it can be assumed that the fruits were in an advanced stage of maturation at the time of production of the blends, since the acidity tends to decrease with ripening and the SST content increase. 
Oliveira et al. (2014) obtained levels of total soluble solids for acerola pulps ranging from 5.57 to $8.27^{\circ} \mathrm{Brix}$. In studies with blends, higher levels were reported. Gomes et al. (2019) worked with blends composed of pineapple, carrots and cabbage sweetened with honey, the authors observed levels of total soluble solids ranging from 11.23 to $13.53{ }^{\circ}$ Brix. Ribeiro et al. (2019) analyzed kiwi blends with passion fruit and obtained levels of total soluble solids 12.0 and $55.66^{\circ}$ Brix for fresh and freeze dried, respectively.

The relationship between total soluble solids and total titratable acidity (SST/ATT) of the formulations produced showed statistical differences between them. The F1 formulation showed a higher value (25.43), possibly due to the greater amount of pitaya in the formulation, and it was observed that as the concentration decreases, the ratio value decreases accordingly.

According to Cardoso et al. (2010) the SST/ATT ratio is the most common measure of flavor, especially sweetness is assessed using this parameter, and if sweetness is high and acidity is low, blends are characterized as sweet. Silva et al. (2016) obtained for this parameter 13.98 in pineapple blends with acerola. Lessa (2019) analyzed the whole pulp of the pitaya fruit, obtaining an average of 39.5 in this parameter.

The ash content varied from 0.44 to $0.57 \%$ in the three formulations. This parameter has no minimum limit required in the current legislation for both pulps used, however, research reports percentages close to the present study. Gadelha et al. (2009), detected a content equivalent to $0.31 \%$, while Lima et al. (2015) $0.19 \%$ in acerola pulp. In blends of beautiful papaya and Indian fig, Silva et al. (2013) reported ash content ranging from 0.34 to $0.47 \%$, close to that obtained in the present study.

Regarding the water content, the formulations showed a high percentage. Note that as the amount of acerola pulp increased, the water content also increased. High levels of water have been reported for acerola and pitaya pulp. Jerônimo et al. (2015) reported levels of 86.03\% and García-Cruz et al. (2013) 87.1 and 89.0\% in pitaya pulp, levels close to that detected in the present study. On the other hand, Reis et al. (2017) and Caetano et al. (2012) obtained, respectively, $90.75 \%$ and $91.17 \%$ in acerola pulp, presenting values above that observed in the present study.

In the analysis of water, lipid and protein activity, it was observed that there was no statistical difference between the three formulations. As for the water activity of the three formulations, the values were higher than 0.9 , which characterizes the blends as high humidity foods ( $\mathrm{Aw}>0.85)$, favoring the deterioration by microorganisms. Thus, care is needed during the processing of blends, as the low water content and water activity favors perishability, thus affecting the stability, quality and composition of the product.

The contents of lipids and proteins were presented in small amounts in the three formulations. However, it is emphasized that the current legislation does not establish minimum limits for these parameters.

Although the content of proteins and lipids showed decreases with higher content of pitaya, it presented a slightly higher protein content than the other samples. De Mello (2014) evaluated the pitaya pulp (H. undatus) in the 2011 and 2012 harvest, which obtained a lipid content of $0.39 \%$ and $0.06 \%$ and protein of $0.84 \%$ and $0.62 \%$. Duarte (2013) and Abreu et al. (2012) obtained mean values of 0.73 and $0.47 \%$ for lipids and 1.33 and $0.87 \%$ for proteins, respectively. Nascimento et al. (2018) observed $0.99 \%$ of lipids in industrial acerola pulp, while in artisanal pulp, this content was not detectable. As for protein content, they detected $2.25 \%$ in artisanal pulp and $2.71 \%$ in industrial pulp.

There was an increase in the ascorbic acid content as the concentration of acerola (F3) increased, differing statistically from the other formulations. In the current legislation, the acerola pulp must present at least 800 (mg.100g) of ascorbic acid, a value higher than that obtained in the present study. Thus, the blends did not meet the requirements for this parameter. However, it is noteworthy that the largest proportions of pulp in the blends were from pitaya, which may justify a low content of ascorbic acid, since this fruit has a low content of this vitamin. (17.7 mg.100 g $\mathrm{g}^{-1}$ ) (Abreu et al., 2012). It is worth mentioning that ascorbic acid is one of the most unstable nutrients, therefore, it needs more attention for the appropriate handling conditions.

When making mixed mango, guava and acerola juices Faraoni et al. (2012) detected levels of ascorbic acid ranging from 29.14 to $69.29 \mathrm{mg} \cdot 100 \mathrm{~mL}^{-1}$, lower than the values of the present study. Souza et al. (2015) featuring two blends of genipap and acerola, found that as the acerola pulp in the formulation increased, there was an increase in the ascorbic acid content (from 156.54 to $257.55 \mathrm{mg} \cdot 100 \mathrm{~g} \mathrm{~g}^{-1}$ ), a behavior similar to that of the study.

As for total sugars, there was a statistical difference between the three formulations. However, formulations F2 and F3 showed a statistical difference for reducing sugars and non-reducing sugars, respectively. In the current 
legislation there is only a minimum content requirement for total sugars is $4\left(\mathrm{~g} \cdot 100 \mathrm{~g}^{-1}\right)$ in the acerola pulp, thus it is observed that the formulations had levels above the minimum required by it.

It is noteworthy that the F1 formulation stood out due to the others, as it presented the highest levels of total sugars $(11.87 \%$ glucose), reducing sugars $(9.18 \%$ glucose) and non-reducing sugars $(4.45 \%$ sucrose). These differences can be justified according to the different points of harvest of the fruits and concentrations of the pulps used in the elaborated formulations.

Carvalho et al. (2017) when analyzing mixed tropical pulp composed of acerola, pineapple, açaí, cashew, cajá and camu-camu obtained values of 9.30 and 10.60 for total sugars using different proportions of the fruits mentioned above. Caetano et al. (2012) when evaluating acerola pulp found levels of 5.26 and 5.14 for reducing sugar (\% glucose) and non-reducing sugar (\% sucrose), respectively. Studies by Silva et al. (2017) and De Mello (2014) found values for reducing sugars for pitaya pulp (H. undatus) of $9.92 \%$ and $9.54 \%$; and non-reducing sugars $1.32 \%$ and $<0.50$, respectively.

Table 2 shows the average values of the color analysis of the blends. The brightness parameter $\left(\mathrm{L}^{*}\right)$ ranges from 0 (black) to 100 (white). When the values are close to 100, the sample is clearer. The luminosity of the F1 formulation showed a higher average, indicating that the blend was lighter. However, there was no statistical difference between formulations F2 and F3.

Formulation F1 showed a high tonality angle. The greater luminosity and shade angle in the F1 formulation are due to the greater amount of pitaya, which has white colored pulp. The $\mathrm{a}^{*}$ coordinate was positive in the three formulations, indicating that the blends were in the red intensity scale and there was a significant difference between the three formulations. In the $b^{*}$ coordinate, the three formulations were positive indicating that they have yellow intensity and there was a significant difference between them. Formulation F3 showed a higher value of $+a^{*},+b^{*}$ and chromatography, due to the higher proportion of acerola pulp.

Table 2. Results of color analysis of pitaya blends with acerola

\begin{tabular}{llll}
\hline Parameters & F1 & F2 & F3 \\
\hline L & $62.88 \pm 0.83 \mathrm{a}$ & $60.73 \pm 0.03 \mathrm{~b}$ & $59.40 \pm 0.46 \mathrm{~b}$ \\
$\mathrm{a}^{*}$ & $4.52 \pm 0.04 \mathrm{c}$ & $8.45 \pm 0.28 \mathrm{~b}$ & $11.29 \pm 0.04 \mathrm{a}$ \\
$\mathrm{b}^{*}$ & $37.43 \pm 0.26 \mathrm{c}$ & $41.23 \pm 0.22 \mathrm{~b}$ & $45.23 \pm 0.55 \mathrm{a}$ \\
Chroma $\left(\mathrm{c}^{*}\right)$ & $37.70 \pm 0.26 \mathrm{c}$ & $42.08 \pm 0.18 \mathrm{~b}$ & $46.62 \pm 0.54 \mathrm{a}$ \\
Tint angle $\left(\mathrm{h}^{*}\right)$ & $83.11 \pm 0.10 \mathrm{a}$ & $78.42 \pm 0.31 \mathrm{~b}$ & $76.00 \pm 0.12 \mathrm{c}$
\end{tabular}

Note. Means followed by the same letter on the line, do not differ statistically from each other by the Tukey test at the level of $5 \%$ probability.

The visual impact caused by color overlaps all other attributes, making this attribute one of the most important in food marketing and thus constituting the first criterion for accepting or rejecting a product (Tocchini \& Mercadante, 2001).

Studying pitaya varieties for juicing, Ochoa-Velasco et al. (2012) observed in the color analysis of the white pitaya pulp the values of the parameters $L^{*}$, $a^{*}$ and $b^{*}$ of $88.94,3.84$ and 5.65, respectively. Sá (2015) obtained average values of the coordinates $\mathrm{L}^{*}, \mathrm{a}^{*}$ and $\mathrm{b}^{*}$ of 88.38 ; 4.48 and 9.41 , respectively, for pitaya pulp.

Silva et al. (2016) obtained in a pineapple blend with $L^{*}$ acerola (28.32); a* (35.30); b* (28.38). Lima et al. (2012) obtained values of $\mathrm{L}^{*}$ (38.23); $\mathrm{a}^{*}$ (32.56); $\mathrm{b}^{*}$ (33.31); $\mathrm{c}^{*}$ (46.96) and $\mathrm{h}^{*}$ (45.43) and Canuto et al. (2010) found for $\mathrm{L}^{*}(23.8) ; \mathrm{c}^{*}(33.2)$ and $\mathrm{h}^{*}(19.6)$ and in acerola pulp.

\section{Conclusions}

The physical-chemical and colorimetric analyzes of the blends showed that the F1 formulation stood out when compared to the others. The parameters $\mathrm{pH}$, soluble solids, ratio SS/ATT, ash, water content, water activity, proteins, sugars, luminosity and shade angle were the ones that gave the formulation (F1) the best results. However, it is noteworthy that the ascorbic acid parameter was shown in greater quantity in sample $\mathrm{F} 3$ as well as higher values of $a^{*}, b^{*}$ and chroma $\left(c^{*}\right)$ in the colorimetric analysis. Therefore, the use of these fruits allows to obtain an innovative product, with excellent nutritional and functional characteristics, and the blend is a viable alternative for the use of ripe, surplus production and seasonal fruits, adding economic value to the product. 


\section{Acknowledgments}

To the Coordination for the Improvement of Higher Education Personnel (CAPES) for granting the scholarship to the first author and to the Universidade Federal de Campina Grande (UFCG/CTRN) for providing the infrastructure facilities used in the research.

\section{References}

Abreu, W. C., Lopes, C. D. O., Pinto, K. M., Oliveira, L. A., Carvalho, G. B.M. D., \& Barcelo, M. D. F. P. (2012). Características físico-químicas e atividade antioxidante total de pitaias vermelha e branca. Revista do Instituto Adolfo Lutz, 71(4), 656-661.

Almeida, S. D. S., Alves, W. A. L., Araujo, S. A. D., Santana, J. C. C., Narain, N., \& Souza, R. R. D. (2014). Use of simulated annealing in standardization and optimization of the acerola wine production. Food Science Technology, 34(2), 292-297. https://doi.org/10.1590/fst.2014.0037

AOAC (Association of Official Analytical Chemistry). (2009). Official methods of analysis of the Association of Official Analytical Chemistry (p. 1115). Washington: AOAC.

Benassi, M. T., \& Antunes, A. J. A. (1988). Comparison of metaphosphoric and oxalic acids as extractant solutions for the determination of vitamin $\mathrm{C}$ in selected vegetables. Arquivos de Biologia e Tecnologia, 31(4), 507-513.

Bezerra, C. V., Silva, L. H. M., Costa, R. D. S., Mattietto, R. A., \& Rodrigues, A. M. C. (2013). Comportamento reológico de suco misto elaborado com frutas tropicais. Brazilian Journal of Food Technology, 16(2), 155-162. https://doi.org/10.1590/S1981-67232013005000020

Bligh, E. G., \& Dyer, W. J. (1959). A rapid method of total lipid extraction and purification. Canadian Journal Biochemistry Physiological, 27(8), 911-917. https://doi.org/10.1139/o59-099

Braga, L. A. C., Penha, F. B., Souza, L. F. A., Braga, A. C. C., Rodrigues, E. C. N., Bezerra, T. S., \& Oliveira, P. D. (2020). Perfil sensorial e avaliação físico-química de néctar misto de Pitaya e Maracujá. Brazilian Journal of Development, 6(6), 38970-38987. https://doi.org/10.34117/bjdv6n6-440

Brasil, Instituto Adolfo Lutz. (2008). Métodos físico-químicos para análise de alimentos (4th ed., p. 1020). São Paulo: IAL.

Brasil, Ministério da Agricultura e do Abastecimento. (2018). Instrução Normativa $n^{\circ} 37$, de 01 de Outubro de 2018. Parâmetros analíticos de suco e de polpa de frutas e a listagem das frutas e demais quesitos complementares aos padrões de identidade e qualidade. Diário Oficial [da] República Federativa do Brasil, Brasília, DF.

Caetano, P. K., Daiuto, E. R., \& Vieitos, R. L. (2012). Característica físico-química e sensorial de geléia elaborada com polpa e suco de acerola. Brazilian Journal of Food Technology, 15(3), 191-197. https://doi.org/10.1590/S1981-67232012005000011

Canuto, G. A. B., Xavier, A. A. O., Neves, L. C., \& Benassi, M. T. (2010). Caracterização físico-química de polpas de frutos da Amazônia e sua correlação com a atividade anti-radical livre. Revista Brasileira de Fruticultura, 32(4), 1196-1205. https://doi.org/10.1590/S0100-29452010005000122

Cardoso, W. S., Pinheiro, F. A., Perez, R., Patelli, T., \& Faria, E. R. (2010). Desenvolvimento de uma salada de frutas: da pesquisa de mercado à tecnologia de alimentos. Ciência e Tecnologia de Alimentos, 30(2), 454-462. https://doi.org/10.1590/S0101-20612010000200024

Carvalho, A. V., Mattietto, R. A., \& Beckman, J. C. (2017). Estudo da estabilidade de polpas de frutas tropicais mistas congeladas utilizadas na formulação de bebidas. Brazilian Journal of Food Technology, 20(1), 1-9. https://doi.org/10.1590/1981-6723.2316

De Mello, F. R. (2014). Avaliação das características físico-químicas e atividade antioxidante da pitaya e determinação do potencial do mesocarpo como corante natural para alimentos (101f., Tese de Doutorado, Universidade Federal Do Paraná, Curitiba).

Delva, L., \& Schneider, R. G. (2013). Antioxidant activity and antimicrobial properties of phenolic extracts form acerola (Malpighia emarginata D.C.) fruit. International Journal of Food Science \& Technology, 48(5), 1048-1105. https://doi.org/10.1111/ijfs.12061

Duarte, M. H. (2013). Armazenamento e qualidade de pitaia [Hylocereus undatus (haw.) britton \& rose] submetida à adubação orgânica (118f., Dissertação de Mestrado, Universidade Federal de Lavras, Lavras). 
Faraoni, A. S., Ramos, A. M., Guedes, D. B., Oliveira, A. N., Lima, T. H. S. F., \& Sousa, P. H. M. (2012). Desenvolvimento de um suco misto de manga, goiaba e acerola utilizando delineamento de misturas. Ciência Rural, 42(5), 911-917. https://doi.org/10.1590/S0103-84782012005000014.

Fernandes, L. M. S. (2011). Conservação frigorificada de pitaya orgânica irradiada (121f., Tese de Doutrorado, Universidade Estadual Paulista, Botucatu).

Gadelha, A. J. F., Rocha, C. O., Vieira, F. F., \& Ribeiro, G. N. (2009). Avaliação de parâmetros de qualidade físico-químicos de polpas congeladas de abacaxi, acerola, cajá e caju. Caatinga, 22(1), 115-118. https://doi.org/10.1590/S0101-20611999000300006

García-Cruz, L., Valle-Guadarrama, S., Salinas-Moreno, Y., \& Joaquín-Cruz, E. (2013). Physical, chemical, and antioxidant activity characterization of pitaya (Stenocereus pruinosus) fruits. Plant foods for Human Nutrition, 68(4), 403-410. https://doi.org/10.1007/s11130-013-0391-8

Gomes, J. S., Silva, A. K., Silva, A. F., Albuquerque, T. N., \& Meireles, B. R. L. A. (2019). Caracterização físico-química de blends composto por abacaxi, cenoura e couve, adoçado com mel. Revista Brasileira de Gestão Ambiental, 13(1), 07-12.

Jerônimo, M. C., Orsine, J. V. C., Borges, K. K., \& Novaes, M. R. C. G. (2015). Chemical and Physical-Chemical Properties, Antioxidant Activity and Fatty Acids Profile of Red Pitaya [Hylocereus undatus (Haw.) Britton \& Rose] Grown in Brazil. Journal of Drug Metabolism \& Toxicology, 6(4), 1-6. https://doi.org/10.4172/2157-7609.1000188

Lemos, D. M., Figueirêdo, R. M. F., Queiroz, A. J. M., Silva, S. F., \& Lima, J. C. B. (2013). Avaliação físico-química de um blend de laranja tangor 'Ortanique' e beterraba. Revista Verde de Agroecologia e Desenvolvimento Sustentável, 7(3), 207-211.

Lessa, F. O. (2019). Caracterização e avaliação sensorial de frutos de pitaya (Hylocereus spp.) (p. 51, Dissertação de Mestrado, Universidade Federal de Pelotas, Pelotas, Brazil).

Lima, L. L. A., Silva, A. M. O., Ferreira, I. M., Nunes, T. P., \& Carvalho, M. G. (2018). Néctar misto de umbu (Spondias tuberosa Arr. Câmera) e mangaba (Hancornia Speciosa Gomes): Elaboração e avaliação da qualidade. Brazilian Journal of Food Technology, 21(1), 1-8. https://doi.org/10.1590/1981-6723.03417

Lima, R. M. T., Figueiredo, R. W., Maia, G. A., Sousa, P. H. M., Figueiredo, E. A. T., \& Rodrigues, C. S. (2012). Chemical, physicochemical and microbiological stability of pasteurized and non pasteurized acerola pulps from organic cultivation. Ciência Rural, 42(2), 367-373. https://doi.org/10.1590/S0103-84782012005 000005

Lima, T. L. S., Cavalcante, C. L., Sousa, D. G., Silva, P. H. A., \& Sobrinho, L. G. A. (2015). Avaliação da composição físico-química de polpas de frutas comercializadas em cinco cidades do Alto Sertão paraibano. Revista Verde de Agroecologia e Desenvolvimento Sustentável, 10(2), 49-55. https://doi.org/10.18378/ rvads.v10i2.3378

Molina, R., Clemente, E., Scapim, M. R. S., \& Vagula, J. M. (2014). Physical Evaluation and Hygroscopic Behavior of Dragon Fruit (Hylocereus undatus) Lyophilized Pulp Powder. Drying Technology, 32(1), 2005-2011. https://doi.org/10.1080/07373937.2014.929587

Nascimento, J. F., Barroso, B. S., Tostes, E. S. L., Silva, A. S. S., \& Silva Júnior, A. C. S. (2018). Análise físico-química de polpas de acerola (Malpighia glabra L.) artesanais e industriais congeladas. Pubvet, 12(6), 1-6. https://doi.org/10.22256/pubvet.v12n6a109.1-6

Nunes, E. N., Sousa, A. S. B., Lucena, C. M., Silva, S.M., Lucena, R. F. P., Alves, C. A. B., \& Alves, R. E. (2014). Pitaia (Hylocereus sp.): Uma revisão para o Brasil. Gaia Scientia, 8(1), 90-98.

Ochoa-Velasco, C. E., Verónica, G. V., José, L. G. J., Lorena, L. G. M., Paola, H. C., \& Ángel, G. B. J. (2012). Características antioxidantes, físico-químicas y microbiológicas de jugo fermentado y sin fermentar de tres variedades de pitahaya (Hylocereus spp.). Scientia Agropecuária, 3(4), 279-289. https://doi.org/10.17268/ sci.agropecu.2012.04.02

Oliveira, T. A., Leite, R. H. De L., Aroucha, E. M. M., De Freitas, T. G. G., \& Santos, F. K. G. (2014). Avaliação da qualidade físico-química de polpas de frutas congeladas na cidade de Mossoró-RN. Revista Verde de Agroecologia e Desenvolvimento Sustentável, 9(2), 248-255. 
Ortiz, T. A., \& Takahashi, L. S. A. (2015). Physical and chemical characteristics of pitaya fruits at physiological maturity. Genetics and Molecular Biology, 14(4), 14422-14439. https://doi.org/10.4238/2015.Novem ber. 18.5

Prakash, A., \& Baskaran, R. (2018). Acerola, an untapped functional superfruit: A review on latest frontiers. Journal of Food Science and Technology, 55(9), 3373-3380. https://doi.org/10.1007/s13197-018-3309-5

Reis, D, S., Neto, A. F., Ferraz, A. V., \& Freitas, S. T. (2017). Produção e estabilidade de conservação de farinha de acerola desidratada em diferentes temperaturas. Brazilian Journal Food Technology, 20(1), 1-7. https://doi.org/10.1590/1981-6723.8315

Ribeiro, V. H. A., Barros, S. L., Santos, N. C., Silva, V. M. A., Melo, M. O. P., \& Nascimento, A. P. S. (2019). Liofilização e caracterização físico-química de blend composto por kiwi e maracujá. Caderno Verde de Agroecologia e Desenvolvimento Sustentável, 9(7), 6834-7084. https://doi.org/10.18378/cvads.v9i7.6834

Sá, A. S. C. (2015). Caracterização química de bebidas fermentadas de pitaia (H. undatus) cultivada no semiárido nordestino (50f., Monografia de Especialização, Instituto Federal de Educação, Ciência e Tecnologia do Sertão Pernambucano, Petrolina).

Silva, A. K., Gomes, J. de S., Alves, M. J. Dos S., Souza, D. G., \& Santos, A. F. (2014). Qualidade em blends de frutas tropicais adicionados de extratos vegetais. Caderno Verde de Agroecologia e Desenvolvimento Sustentável, 4(1), 1-6.

Silva, F. A. S., \& Azevedo, C. A. V. (2016). The Assistat Software Version 7.7 and its use in the analysis of experimental data. African Journal of Agricultural Research, 11(39), 3733-3740. https://doi.org/10.5897/ AJAR2016.11522

Silva, J. H. F., Soares, S. J. L., Gomes, G. M. S., Souza, I. B., \& Silva, M. M. (2017). Physical-chemical characterization and sensory evaluation of pitaya (Hylocereus undatus) cultivated in the Southern Agreste Pernambucano. Revista Brasileira de Agrotecnologia, 7(2), 260-265.

Silva, M. J. S., Rocha, A. P. T., Santos, D. C., Araújo, A. S., \& Oliveira, M. N. (2016). Caracterização físico-química de blend de abacaxi com acerola obtido pelo método de liofilização. Revista Verde de Agroecologia e Desenvolvimento Sustentável, 11(5), 110-113. https://doi.org/10.18378/rvads.v11i5.4786

Silva, S. F., Figueirêdo, R. M. F., Queiroz, A. J. M., Lemos, D. M., \& Lima, J. C. B. (2013). Caracterização de blends de mamão formosa e figo-da-índia. Revista Verde de Agroecologia e Desenvolvimento Sustentável, 7(3), 202-206.

Souza, L. S., Fonseca, A. A. O., Santa Bárbara, M. F., Teixeira, M. B., \& Sant'ana, R. S. (2015). Processamento e caracterização de um “blend” de jenipapo e acerola. Journal of Fruits and Vegetables, 1(1), 31-34.

Tocchini, L., \& Mercadante, A. Z. (2001). Extração e determinação, por CLAE, de bixina e norbixina em caloríficos. Ciência e Tecnologia de Alimentos, 21(3), 43-45. https://doi.org/10.1590/S0101-206120010 00300010

Wong, Y. M., \& Siow, L. F. (2015). Effects of heat, pH, antioxidant, agitation and light on betacyanin stability using red-fleshed dragon fruit (Hylocereus polyrhizus) juice and concentrate as models. Journal of Food Science and Technology, 52(5), 3086-3092. https://doi.org/10.1007/s13197-014-1362-2

\section{Copyrights}

Copyright for this article is retained by the author(s), with first publication rights granted to the journal.

This is an open-access article distributed under the terms and conditions of the Creative Commons Attribution license (http://creativecommons.org/licenses/by/4.0/). 